\title{
Forecasting Sclerotinia Disease on Lettuce: Toward Developing a Prediction Model for Carpogenic Germination of Sclerotia
}

\author{
John P. Clarkson, Kath Phelps, John M. Whipps, Caroline S. Young, Julie A. Smith, and Martyn Watling
}

First, second, and third authors: Horticulture Research International, Wellesbourne, Warwick, CV35 9EF, UK; fourth and fifth authors: ADAS Consulting Ltd., ADAS Wolverhampton, Woodthorne, Wergs Road, Wolverhampton, WV6 8TQ, UK; and sixth author: ADAS Consulting Ltd., ADAS Terrington, Terrington St Clement, King's Lynn, Norfolk PE34 4PW, UK. Accepted for publication 7 November 2003 .

\begin{abstract}
Clarkson, J. P., Phelps, K., Whipps, J. M., Young, C. S., Smith, J. A., and Watling, M. 2004. Forecasting Sclerotinia disease on lettuce: Toward developing a prediction model for carpogenic germination of sclerotia. Phytopathology 94:268-279.

The feasibility of developing a forecasting system for carpogenic germination of Sclerotinia sclerotiorum sclerotia was investigated in the laboratory by determining key relationships among temperature, soil water potential, and carpogenic germination for sclerotia of two $S$. sclerotiorum isolates. Germination of multiple burials of sclerotia to produce apothecia also was assessed in the field with concurrent recording of environmental data to examine patterns of germination under different fluctuating conditions. Carpogenic germination of sclerotia occurred between 5 and $25^{\circ} \mathrm{C}$ but only for soil water potentials of $\geq-100 \mathrm{kPa}$ for both $\mathrm{S}$. sclerotiorum isolates. Little or no germination occurred at 26 or $29^{\circ} \mathrm{C}$. At optimum temperatures of 15 to $20^{\circ} \mathrm{C}$, sclerotia

buried in soil and placed in illuminated growth cabinets produced stipes after 20 to 27 days and apothecia after 27 to 34 days. Temperature, therefore, had a significant effect on both the rate of germination of sclerotia and the final number germinated. Rate of germination was correlated positively with temperature and final number of sclerotia germinated was related to temperature according to a probit model. Thermal time analysis of field data with constraints for temperature and water potential showed that the mean degree days to $10 \%$ germination of sclerotia in 2000 and 2001 was 285 and 279 , respecttively, and generally was a good predictor of the observed appearance of apothecia. Neither thermal time nor relationships established in the laboratory could account for a decline in final percentage of germination for sclerotia buried from mid-May compared with earlier burials. Exposure to high temperatures may explain this effect. This, and other factors, require investigation before relationships derived in the laboratory or thermal time can be incorporated into a forecasting system for carpogenic germination.
\end{abstract}

Sclerotinia sclerotiorum is a nectrotrophic pathogen with worldwide distribution known to infect over 400 species of plants (8). Field-grown lettuce is particularly affected in the United Kingdom and a typical loss of $15 \%$ would amount to a farm gate loss of $£ 9.5$ million in 2001 (12). The sclerotia of the pathogen survive in soil for several years and may infect host plants directly, by production of mycelium, or indirectly, by production of ascospores from apothecia which then infect the plant. The majority of hosts, including lettuce, are infected indirectly through ascospores $(5,28,30)$ and, hence, apothecial production through carpogenic germination of sclerotia is a fundamental part of the pathogen's life cycle.

Currently, control of Sclerotinia disease on lettuce relies on the application of fungicides that prevent infection by ascospores. However, limits on the permitted number of sprays make it essential to target their timing in order to accurately achieve effective disease control and avoid prophylactic spraying. One way of doing this would be to develop a forecasting system to predict when apothecia and, hence, ascospores appear in the field. This seems to be a worthwhile strategy because Sclerotinia disease generally is restricted to areas where apothecia appear (7) and the majority of ascospores are deposited close to the source $(9,40)$. Such an approach has been suggested in the past $(7,31)$ but has not been developed. Only one forecasting system has been published for Sclerotinia disease (38), where a risk-point table based on regional risk of apothecium development, weather factors, previous cropping, and disease levels was used to predict whether

Corresponding author: J. P. Clarkson; E-mail address: john.clarkson@hri.ac.uk

Publication no. P-2004-0112-01R

(c) 2004 The American Phytopathological Society fungicides should be applied. However, the component of apothecium development risk was based on actual observations of sclerotia buried in the field each year.

Developing a forecasting system to predict the carpogenic germination of S. sclerotiorum sclerotia requires detailed knowledge of the effect of important environmental factors on this process. Soil water potential, temperature, light, soil type, depth of burial, and isolate origin all have been shown to affect production of apothecia $(2,4,30)$, but temperature and water potential are arguably the major limiting factors $(2,30)$. Rather confusingly, a wide range of optimum and minimum requirements for these parameters have been reported. In laboratory studies using different water potentials, Grogan and Abawi (16) observed that apothecia were produced from sclerotia on tap water agar at $0 \mathrm{kPa}$ but not when adjusted to $-600 \mathrm{kPa}$. More recently, laboratory studies by Hao et al. (18) in soil showed that there was no or little germination of S. sclerotiorum sclerotia to produce apothecia at $-300 \mathrm{kPa}$. In the glasshouse, Teo and Morrall (37) used a novel inclined-box technique to show that most apothecia were produced in soil between -11 and $-40 \mathrm{kPa}$, but that some also were produced at water potentials as low as $-400 \mathrm{kPa}$. In the field, 1 to 2 weeks $>-30 \mathrm{kPa}$ (24) and 2 weeks $>-500 \mathrm{kPa}$ (6) have been reported as being necessary for carpogenic germination. In addition, Ferraz et al. (14) showed that apothecia were produced in field microplots only where water potential was kept above $-54 \mathrm{kPa}$, with more produced in plots kept above $-25 \mathrm{kPa}$. The reported effect of temperature on apothecial production by S. sclerotiorum sclerotia is just as varied (30), not least perhaps because it has been shown that requirements are different for isolates of different geographic origin, and also depend on the temperature at which the sclerotia formed (22). For instance, sclerotia formed at $10^{\circ} \mathrm{C}$ from isolates originating from cool, temperate regions produced apothecia more 
readily than those produced at 25 to $30^{\circ} \mathrm{C}$. Moreover, apothecial production was poor for sclerotia of isolates from warmer climatic regions formed at either temperature regime unless a period of cold conditioning at $10^{\circ} \mathrm{C}$ was applied. Such a conditioning period generally is required for most $S$. sclerotiorum isolates to ensure carpogenic germination of sclerotia formed at $\approx 20^{\circ} \mathrm{C}$ or above, and standard treatments used by researchers are either 5 or $10^{\circ} \mathrm{C}$ for 4 weeks $(21,27,32,35)$. In the U.K. field situation, sclerotia naturally would receive sufficient cold conditioning during the winter, with apothecia appearing in spring as soil temperatures rise (30). However, given sclerotia that are preconditioned for carpogenic germination, the reported temperature ranges and optima for subsequent apothecial production are variable. Abawi and Grogan (1) reported a range of 10 to $25^{\circ} \mathrm{C}$ with an optimum of $10^{\circ} \mathrm{C}$, Kruger $(25)$ a range of 7 to $11^{\circ} \mathrm{C}$, and Sun and Yang (36) a range of 12 to $30^{\circ} \mathrm{C}$ with an optimum of $\approx 20^{\circ} \mathrm{C}$. More recently, Hao et al. (18) reported an optimal range of 10 to $20^{\circ} \mathrm{C}$ with limited germination at $5^{\circ} \mathrm{C}$ and no germination at 25 or $30^{\circ} \mathrm{C}$. Researchers have used $10^{\circ} \mathrm{C}(27,32), 15^{\circ} \mathrm{C}(1,26,33)$, or $20^{\circ} \mathrm{C}(13,22,23)$ for experiments on different aspects of apothecial production.

The effect of temperature and water potential on apothecial production is complex and the literature difficult to interpret. A major problem is that, very often, the effect of water potential has not been assessed at constant temperature (as for studies carried out in the field and glasshouse) or an inadequate range of soil water potentials has been used. Similarly, most temperature studies generally have addressed only a single water potential. However, this situation has begun to be addressed recently because Hao et al. (18) tested the effect of a range of soil water potentials at different temperatures on the number of sclerotia producing apothecia after 12 weeks for Californian isolates of $S$. sclerotiorum.

The aim of this study was to investigate the feasibility of developing a prediction model for the carpogenic germination of $S$. sclerotiorum sclerotia in the field based on their response to temperature and soil water potential. Laboratory and field studies were carried out using two $S$. sclerotiorum isolates. These represented contrasting U.K. locations and soil types where lettuce is grown and allowed the detection of any differences in response of the isolates to environmental factors. In the laboratory, the effect of a range of soil temperatures and water potentials on the carpogenic germination of sclerotia of both $S$. sclerotiorum isolates was determined so that an analysis could be performed to derive key relationships. In the field, the production of apothecia by multiple burials of sclerotia of the two S. sclerotiorum isolates was monitored at their location of origin and environmental data recorded in 2 years. This system allowed sclerotia to be exposed to a wide range of weather conditions each year. This dual approach of investigating carpogenic germination both in the laboratory and field provided an opportunity to detect unexpected effects that might invalidate any forecasting system based solely on relationships derived from laboratory data when applied under field conditions.

\section{MATERIALS AND METHODS}

Sclerotinia sclerotiorum isolates and production of sclerotia. The two isolates of $S$. sclerotiorum used in this study were derived from sclerotia on diseased lettuce plants grown on a Cheshire peat soil (Turbary Moor Series; isolate 13; IMI 390053) and a Norfolk silty clay loam (Blacktoft Series; isolate TM; IMI 390054). These two locations represented contrasting lettucegrowing areas in the United Kingdom because they had different soil types and were separated geographically, so that they were exposed to different weather conditions. Original isolations were made by surface sterilizing sclerotia in $50 \%$ ( $\mathrm{vol} / \mathrm{vol}$ ) sodium hypochlorite and $70 \%$ ethanol for 4 min with agitation, followed by two washes in sterile, distilled water for $1 \mathrm{~min}$. Each sclerotium then was bisected, placed on potato dextrose agar (PDA; Oxoid, Basingstoke, UK), and incubated at $20^{\circ} \mathrm{C}$. Isolates 13 and TM were selected through preliminary experiments from 20 sclerotial isolations from each location for their ability to produce uniform-sized sclerotia in culture which would germinate carpogenically to form apothecia under appropriate conditions. Stock sclerotia of each isolate were picked out from 4-week-old cultures grown on PDA and were stored at $10^{\circ} \mathrm{C}$ in petri dishes. To provide sclerotia for experiments, stock sclerotia were surface sterilized and bisected as before, placed on PDA, and incubated for 4 days at $20^{\circ} \mathrm{C}$, after which there was adequate mycelial growth without sclerotial initiation. Agar plugs $\left(\approx 3 \mathrm{~mm}^{2}\right)$ from the edge of the colonies then were used to inoculate sterile wheat grain $(25 \mathrm{~g}$ of wheat grain, $50 \mathrm{~g}$ of water autoclaved at $121^{\circ} \mathrm{C}$ for $15 \mathrm{~min}$ ) in 500 -ml conical flasks. Flasks were incubated at $18^{\circ} \mathrm{C}$ for 4 weeks, after which sclerotia had formed and matured. During this time, the flasks were shaken gently by hand biweekly to encourage formation of uniform sclerotia and prevent clumping of wheat grains and mycelia (32). Flasks then were incubated at $4^{\circ} \mathrm{C}$ for 8 to 20 weeks as a cold-conditioning treatment for the sclerotia to ensure adequate carpogenic germination in experiments $(27,32)$. After this period, sclerotia were wet sieved to recover those between 2 and $5 \mathrm{~mm}$ and the wheat grain was floated off. Finally, the sclerotia were dried in an air flow overnight, after which they were used immediately in experiments.

Effect of temperature and water potential on apothecial production. Carpogenic germination of sclerotia of S. sclerotiorum isolates 13 and TM to produce both stipes and apothecia was assessed at different temperatures and water potentials in the peat and silty clay loam soils, respectively, in growth cabinets with white fluorescent lighting (12-h day; $\left.20 \mathrm{Wm}^{2}\right)$. The peat and silty clay loam soils used in all experiments first were passed through a $2-\mathrm{mm}$ sieve and then pasteurized by autoclaving volumes of approx. 6 liters for $30 \mathrm{~min}$ at $110^{\circ} \mathrm{C}$. Previous experiments had shown that this removed fungi which potentially could contaminate and interfere with the germination of $S$. sclerotiorum sclerotia (data not shown). Other researchers have found that sterilizing soil has no effect on carpogenic germination (33). The percent soil moisture content of both soil types (grams of water/ [grams of water + grams of dry soil] $\times 100=$ percent moisture content [mc]) was assessed before use by weighing three samples of each soil before and after drying in an oven at $80^{\circ} \mathrm{C}$ overnight. A soil moisture release curve for each soil type was obtained by desorption of saturated soil in a standard pressure plate apparatus.

Initially, $100 \mathrm{~g}$ of the peat and $150 \mathrm{~g}$ of the silty clay loam were dispensed into clear plastic boxes (600-ml volume; Malsar Kest Ltd., London, UK) with clip-on lids. These represented equivalent volumes at the moisture contents typically found after pasteurization which were $\approx 5$ and $50 \%$ mc for the silty clay loam and peat soils, respectively. Water was added (by drop with pipette) or removed (laminar air flow) with thorough mixing to give a full range of soil water potentials from air-dried soil (which would not support sclerotial germination) to saturation. The water potentials tested for the peat soil were $-383,-109,-30,-9,-2$, and $-0.2 \mathrm{kPa}$ (equivalent to $40,45,50,55,60$, and $65 \% \mathrm{mc}$ ) and for the silty clay loam soil were $-412,-107,-30,-9,-4,-2$, and $-1.8 \mathrm{kPa}$ (equivalent to $12,15,18,21,24,27$, and $30 \% \mathrm{mc}$ ). Sclerotia (30) of Sclerotinia isolates 13 or TM then were arranged in a grid formation on top of the soil surface and covered to a 1-cm depth with the appropriate soil (equivalent to $23 \mathrm{~g}$ of peat soil and $35 \mathrm{~g}$ of silty clay loam soil). Further water was added to this top layer of soil or removed beforehand as appropriate for the desired water potential. Two experiments were carried out for each $S$. sclerotiorum isolate in its own soil type. The first tested the range of water potentials for each at 10,15 , and $20^{\circ} \mathrm{C}$ and the second tested the same water potentials at 18,22 , and $25^{\circ} \mathrm{C}$. Each experiment included three replicate boxes for each temperature- 
water potential combination for each isolate. Stipe and apothecial appearance were monitored weekly. A stipe was considered to have matured into an apothecium when a distinct cap was observed which was $\geq 4 \mathrm{~mm}$ in diameter. Temperature was monitored in each growth cabinet every 30 min using a Squirrel 800 logger (Grant Instruments, Cambridge, UK) for the duration of experiments.

Effect of temperature and water potential on stipe production. Carpogenic germination of sclerotia of S. sclerotiorum isolates 13 and TM also was assessed in terms of stipe production in unlit incubators at different temperatures and soil water potentials in the Cheshire peat and Norfolk silty clay soils, respectively. This system allowed the full range of water potentials to be tested easily for a wider temperature range than in the previous experiments, without the need for multiple specialist illuminated growth chambers. Hence, a more complete temperature response by sclerotia of $S$. sclerotiorum could be determined at the different water potentials. Although light is necessary for apothecia to develop from stipes (30), previous unpublished experiments confirmed that the stipes from $S$. sclerotiorum sclerotia produced in this unlit system developed normally into apothecia if placed in a growth chamber with lighting.

The peat and silty clay loam soils used in all experiments were first sieved and pasteurized as described before. The silty clay loam (42 g) and peat $(20 \mathrm{~g})$ soils then were dispensed into $9-\mathrm{cm}$ petri dishes to give equivalent volumes and a depth of $\approx 1 \mathrm{~cm}$. To produce the range of water potentials for each soil type, water was added by drops or removed by drying appropriately, as described before. The water potentials tested were as before: -383 , $-109,-30,-9,-2$, and $-0.2 \mathrm{kPa}$ for the peat soil and $-412,-107$, $-30,-9,-4,-2$, and $-1.8 \mathrm{kPa}$ for the silty clay loam. The soil in each petri dish was tamped gently with a rubber bung for an even distribution in the dish and a level surface. Sclerotia (26) of each Sclerotinia isolate then were placed in a grid formation in each dish of the appropriate soil and again gently tamped with a rubber bung so that the top surface of the sclerotia was level with the soil but was not covered. This allowed stipes to be observed as soon as they appeared. Petri dishes were placed in incubators at a range of temperatures in sealed plastic boxes and germination of sclerotia was assessed every 3 to 7 days. A sclerotium was considered to have germinated when one or more stipes was greater than $2 \mathrm{~mm}$ in length. To detect the few cases where stipes were produced by sclerotia from the bottom rather than from the top exposed surface, sclerotia were turned using forceps and then replaced. Two experiments were carried out for each Sclerotinia isolate, the first testing the standard range of soil water potentials for each soil type at $5,10,15,20$, and $25^{\circ} \mathrm{C}$, and the second testing the same water potentials at $20,23,26$, and $29^{\circ} \mathrm{C}$. In each experiment, there were three replicate petri dishes for each temperature-water potential combination for each isolate. Temperature was monitored in incubators with a logger as before.

Effect of high temperature durations on stipe production. The methodology described above also was used to test the effect of different durations of high soil temperature on carpogenic germination of sclerotia to produce stipes. A preliminary experiment had shown that sclerotia of $S$. sclerotiorum isolate 13 exposed to 7 weeks at $29^{\circ} \mathrm{C}$ in peat soil at -2 or $-383 \mathrm{kPa}$ germinated normally when transferred to $15^{\circ} \mathrm{C}$ and a water potential of $-2 \mathrm{kPa}$. In view of this and the fact that temperatures of up to $40^{\circ} \mathrm{C}$ had been recorded in the soil in field experiments (described below), sclerotia of S. sclerotiorum isolates 13 and TM were exposed to durations of $4,8,12,24,48$, and $72 \mathrm{~h}$ at temperatures of 35 and $40^{\circ} \mathrm{C}$ in appropriate soil at $-2 \mathrm{kPa}$ in petri dishes. After exposure to these durations of high temperature, sclerotia then were incubated at $15^{\circ} \mathrm{C}$ (still at $-2 \mathrm{kPa}$ ) and germination recorded twice a week for up to 10 weeks. There were three replicate petri dishes for each temperature duration and the temperature in incubators was monitored with a logger as before.
Apothecial production by sclerotia in the field. Sclerotia of S. sclerotiorum isolates 13 and TM were buried in bare soil at field sites in Rixton, Cheshire and Terrington, Norfolk every 2 weeks between April and August 2000 and between March and August 2001. The sites corresponded to the original soil type and location of each $S$. sclerotiorum isolate. Therefore, sclerotia were exposed to a range of environmental conditions found during the U.K. lettuce-growing season. Sclerotia of each isolate were produced and conditioned in the laboratory as described before. A total of 200 sclerotia were buried every 2 weeks in grids laid over the soil surface at each location in 2000 (four grids of 50 sclerotia), with 400 sclerotia buried every 2 weeks in 2001 (four grids of 100 sclerotia). Sclerotia were buried at a depth of $\approx 1 \mathrm{~cm}$ in the grid cells and the grids were arranged in a randomized block design. The appearance of apothecia was recorded once or twice a week and a sclerotium of $S$. sclerotiorum was considered to have germinated when one or more apothecia had been recorded in a grid cell. Environmental conditions were monitored every 30 min using a data logger (Delta-T Instruments, Cambridge, UK) recording rainfall, soil temperature, and soil water potential. At each burial time, samples of sclerotia $(2 \times 25)$ also were buried in mesh bags adjacent to the grid area. Six weeks after each burial, these sclerotia were retrieved and checked for degradation by counting those remaining after rubbing over a $2-\mathrm{mm}$ sieve to remove any that were soft and degraded. Sclerotia that were buried in 2000 and had not germinated in that same year continued to be monitored for apothecial production in 2001.

Analyses of laboratory data. For the laboratory experiments investigating stipe and apothecial production by sclerotia, the number of sclerotia germinating in each replicate was converted to a percentage and mean values plotted against time. To provide an estimate of the variability among the replicates, analyses of variance were performed after logit transformation of the final percentage of sclerotia germinated for all the water potential treatments at each temperature. For each water potential, a standard error of the mean was calculated corresponding to a final sclerotial germination value of $50 \%$. To compare the effect of each $S$. sclerotiorum isolate, temperature and soil water potential data were averaged over the three replicates and summarized into two response variates before statistical analysis. The variates were (i) the final percentage of sclerotia that had germinated by the end of the experiments and (ii) the interpolated time (in days) corresponding to when $50 \%$ of the total sclerotia had germinated. Treatments where germination did not occur were not included in analyses of either variate. Treatments where germination was less than $50 \%$ could not be included in the analysis of variate 2 . The final percent germination of sclerotia was analyzed using a generalized linear model with binomial errors and probit link function and the times to $50 \%$ germination were converted to rates (1/time to $50 \%$ germination) before performing a regression analysis. For both variates, the three-factor interaction (S. sclerotiorum isolate, temperature, and soil water potential) was incorporated into the error term to provide more degrees of freedom. Data from experiments investigating stipe production were used to derive a relationship between temperature and final percent germination of sclerotia. These data were used because a greater range of temperatures had been tested compared with the experiments assessing production of apothecia. For the stipe data, the final percentage of germination for water potentials of $\geq-30 \mathrm{kPa}$ was plotted against temperature for both $S$. sclerotiorum isolates. The resulting curve was described by the probit model proposed by Finney (15). For each sclerotium, it is assumed that there is a threshold temperature above which germination cannot proceed and the following equation applies:

$$
p(T)=\Phi(\alpha+\beta T)
$$

where $p(T)$ is the proportion of sclerotia germinating at temperature $T$ and $\Phi$ is the normal probability integral. 
Analyses of field data. Germination of sclerotia buried in the field was summarized as final percent germinated and time to germination, and also inspected visually in conjunction with meteorological data. In fluctuating environmental conditions, chronological time is meaningless; therefore, time to appearance of apothecia was summarized in terms of thermal time as accumulated day-degrees. This involves accumulating time where the temperature is above a base to predict when an event such as germination of sclerotia will occur (41). The accumulated daydegrees to reach $10 \%$ (T10) and 50\% (T50) germination of $S$. sclerotiorum sclerotia for burials made at Cheshire in 2000 and 2001 were investigated as predictors for the observed appearance of apothecia. In a conventional day-degree calculation, a temperature reading $X$ during a half-hour period would contribute $(X-$ $B) / 48$ to the day-degree accumulation, provided that $X$ was above the threshold temperature $B$; there would be no contribution if $X$ were below $B$. In this study, the calculation was modified according to results obtained in the laboratory, so that there was no contribution if the temperature was above or below certain thresholds or if the water potential was below a certain threshold. Hence, for each burial at Cheshire in each year, T10 and T50 were expressed in terms of accumulated day-degrees calculated with different combinations (a factorial set) of temperature and water potential threshold values. For each member of this set, the accumulated day-degrees for T10 and T50 were averaged across burials to provide the mean thermal time required for the appearance of apothecia in 2000 and 2001. For each burial, this value then was converted to a prediction of germination in terms of chronological time (i.e., days after burial). The predictions obtained then were compared with the mean observed chronological time to 10 and $50 \%$ germination for all the burials. The accuracy of the predictions for appearance of apothecia from the buried sclerotia was summarized by the root mean square error value (RMSE) given by

$$
\mathrm{RMSE}=\sum_{\text {burials }}\left(\frac{(\text { ObsT }- \text { PredT })^{2}}{(b-1)}\right)
$$

where ObsT $=$ observed time (days) to $\mathrm{T} 10$ or $\mathrm{T} 50$, PredT $=$ predicted time (days) to T10 or T50 and $b=$ number of burials of sclerotia where 10 or $50 \%$ germination was achieved. A smaller value in RMSE indicates a better prediction. To compare the rate of germination of $S$. sclerotiorum isolate 13 sclerotia in the field at Cheshire with the rate of germination for the same isolate obtained under controlled conditions in the laboratory, the number of day-degrees calculated from the thermal time analysis also was used to calculate rates of germination corresponding to the constant temperatures used in the laboratory experiments. For $D$ daydegrees above a base temperature $B, 50 \%$ germination occurs after time $D /(X-B)$ at a constant temperature of $X$ and the rate of germination is then $(X-B) / D$.

\section{RESULTS}

Effect of temperature and water potential on apothecial production. Apothecia were produced by sclerotia of S. sclerotiorum isolates 13 and $\mathrm{TM}$ for the temperature range tested of between 10 and $25^{\circ} \mathrm{C}$ (Fig. 1). Results for both isolates where soil water potential was $<-2 \mathrm{kPa}(65 \% \mathrm{mc}$ for the peat soil and $30 \%$ for the silty clay loam) and the results from the $-4 \mathrm{kPa}(24 \% \mathrm{mc})$ treatment in the silty clay loam soil were omitted from the graphs because they were almost identical to the $-2 \mathrm{kPa}$ results. Few apothecia were produced by isolate 13 at $-109 \mathrm{kPa}$ for the peat soil or by isolate $\mathrm{TM}$ at $-107 \mathrm{kPa}$ for the silty clay loam. These apothecia also were much smaller compared with those developing in wetter soil treatments for both S. sclerotiorum isolates. The driest soil treatments of $-383 \mathrm{kPa}$ for the peat soil and $-412 \mathrm{kPa}$ for the silty clay loam did not support any apothecial production by sclerotia. Apothecia appeared after 27 to 34 days for both $S$. sclerotiorum isolates at 15 to $20^{\circ} \mathrm{C}$ for those water potentials supporting sclerotial germination. Stipes from these sclerotia were first observed after 20 to 27 days; therefore, on average, apothecia developed from stipes after a further 7 to 14 days at these temperatures. Reducing the temperature to $10^{\circ} \mathrm{C}$ decreased the rate of sclerotial germination considerably for both $S$. sclerotiorum isolates compared with 15 or $18^{\circ} \mathrm{C}$, so that stipes from sclerotia of isolates 13 and TM were first observed after 39 to 41 days, with apothecia developing after 48 to 54 days.

Data from both experiments and for both $S$. sclerotiorum isolates were combined for statistical analyses. Analysis of both the final percentage of sclerotia germinated to produce apothecia and the germination rate indicated that there were significant effects of temperature $(P \leq 0.001)$ and interactions between isolate and temperature $(P \leq 0.01)$. In addition, final percent germination was affected by water potential $(P \leq 0.001)$ and there also was an interaction between isolate and water potential $(P \leq 0.001)$. There was no interaction between temperature and water potential $(P=0.05)$.

Effect of temperature and water potential on stipe production. Stipes were produced between 5 and $25^{\circ} \mathrm{C}$ by sclerotia of both $S$ sclerotiorum isolates, but only at soil water potentials of $\geq-109 \mathrm{kPa}$ for the peat soil and $\geq-107 \mathrm{kPa}$ for the silty clay loam (Fig. 2). For clarity, only data from the first experiment $(5,10,15$, 20 , and $25^{\circ} \mathrm{C}$ ) are presented graphically here. Treatments for both isolates where water potential was $<-2 \mathrm{kPa}$ and the results from the $-4 \mathrm{kPa}$ treatment in the silty clay loam soil also were omitted because they were almost identical to the $-2 \mathrm{kPa}$ results. The driest soil treatments $(-383 \mathrm{kPa}$ for the peat soil and $-412 \mathrm{kPa}$ for the silty clay loam) did not support carpogenic germination of sclerotia.

In the second experiment at 20 and $23^{\circ} \mathrm{C}$, germination of both isolates followed a similar pattern to that at $20^{\circ} \mathrm{C}$ in the first experiment for all water potentials (data not shown) and, again, there was no germination below $\approx-100 \mathrm{kPa}$. However, at 26 and $29^{\circ} \mathrm{C}$, there was little or no germination of S. sclerotiorum sclerotia for either isolate. At temperatures between 15 and $20^{\circ} \mathrm{C}$, stipes were first recorded between 9 and 19 days after sclerotia were placed in soil but, at $10^{\circ} \mathrm{C}$, stipes appeared after 31 days for isolate 13 and after 20 days for isolate TM. At $5^{\circ} \mathrm{C}$, the time of first stipe appearance increased to 63 days for isolate 13 and 37 days for isolate TM.

Data from both experiments and for both S. sclerotiorum isolates were combined for statistical analyses. Analysis of both the final percent sclerotia germinated to produce stipes and the germination rate indicated that there were significant effects of temperature $(P \leq 0.001)$ and interactions between isolate and temperature ( $P \leq 0.001$ for final percent germination and $P \leq 0.05$ for germination rate). Final percent germination also was affected by water potential $(P \leq 0.001)$, but there were no other significant effects.

The interactions between S. sclerotiorum isolate and temperature meant that further analysis of the effect of temperature on final percent sclerotia germinated (stipe data) was conducted for each isolate separately. Generally, the final percent sclerotia germinated was affected little by water potential, providing the latter was $\geq-109 \mathrm{kPa}$ for both $S$. sclerotiorum isolates. When final percent sclerotia germinated for water potentials of $\geq-30 \mathrm{kPa}$ was plotted against temperature, there was a clear relationship described by the fitted probit curves for each isolate (Fig. 3); therefore, it was evident that the significant effects of water potential on final germination were due mostly to the data from treatments at -107 and $-109 \mathrm{kPa}$. For both $S$. sclerotiorum isolates there clearly was a rapid decline in germination between 20 and $25^{\circ} \mathrm{C}$. The shape of the temperature response curves in Figure 3 also suggests that, over the range of temperatures studied, there is an upper temperature limit which varies among sclerotia within the population of sclerotia of each isolate according to a normal dis- 
tribution. The parameters of these distributions were estimated from the fitted probit curves. For isolate 13, the probit parameters ( \pm standard error) were $\alpha=6.28 \pm 2.57$ and $\beta=0.279 \pm 0.116$ and for isolate TM were $\alpha=4.66 \pm 1.17$ and $\beta=0.205 \pm 0.055$.

Germination rates of sclerotia of each $S$. sclerotiorum isolate to produce stipes (dark incubators) or apothecia (illuminated growth cabinets) were strongly positively correlated with temperature. For production of stipes, $R^{2}$ values were 0.54 and 0.79 for isolate

\section{S. sclerotiorum isolate 13 in Cheshire peat}
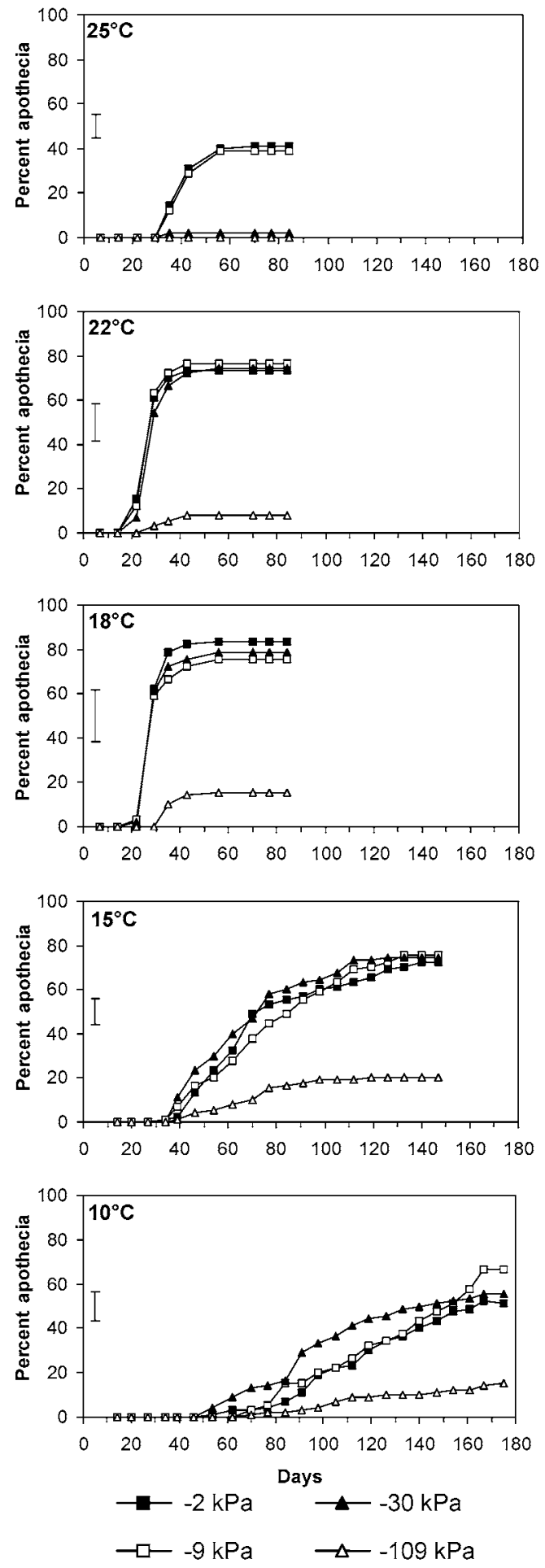

TM and 13, respectively, and 0.82 for production of apothecia by isolate 13 . Only three germination rate values could be calculated for production of apothecia by isolate TM because temperatures of 22 and $25^{\circ} \mathrm{C}$ tested resulted in less than the $50 \%$ germination required. Although there was a strong correlation between germination rate and temperature, no further analysis was attempted because there were not enough data to accurately determine the shape of the rate-temperature curve. Generally, however, rates for

\section{S. sclerotiorum isolate TM in Norfolk silty clay}
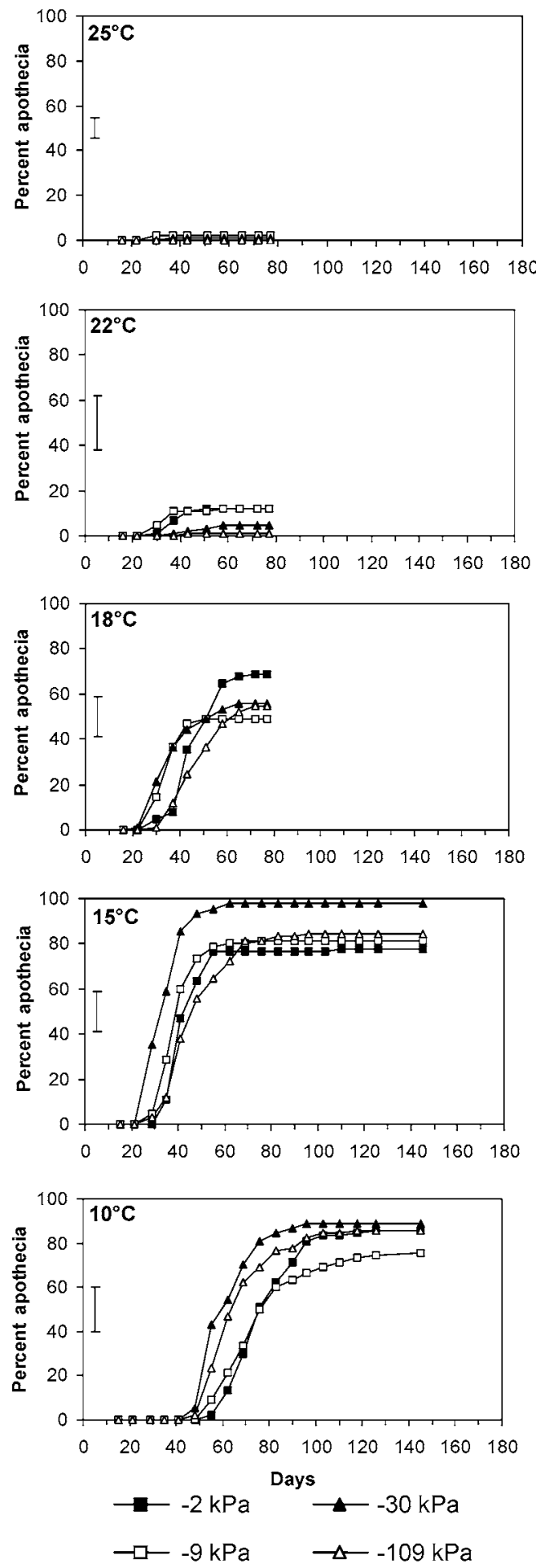

Fig. 1. Effect of water potential on percentage of Sclerotinia sclerotiorum sclerotia producing apothecia for isolate 13 in a Cheshire peat $(-2,-9,-30$, and $-109 \mathrm{kPa}$ ) and TM in a Norfolk silty clay loam $(-2,-9,-30$, and $-107 \mathrm{kPa})$ at $10,15,18,22$, and $25^{\circ} \mathrm{C}$. Each data point is the mean of three replicates of 30 sclerotia. Bars represent standard error of the mean. There was no germination of sclerotia of S. sclerotiorum isolate 13 at $-383 \mathrm{kPa}$ in the peat soil or isolate TM at $-412 \mathrm{kPa}$ in the silty clay loam at any temperature. 
a given temperature were similar for both isolates and, not unexpectedly, rates were consistently faster for the stipe data than the apothecia data (data not shown).

Effect of high temperature durations on stipe production. Carpogenic germination was delayed when sclerotia of S. sclerotiorum isolate 13 or TM were exposed to longer durations at $40^{\circ} \mathrm{C}$ before incubation at $15^{\circ} \mathrm{C}$ (Fig. 4). For isolate 13, stipe pro-

\section{S. sclerotiorum isolate 13 in Cheshire peat}
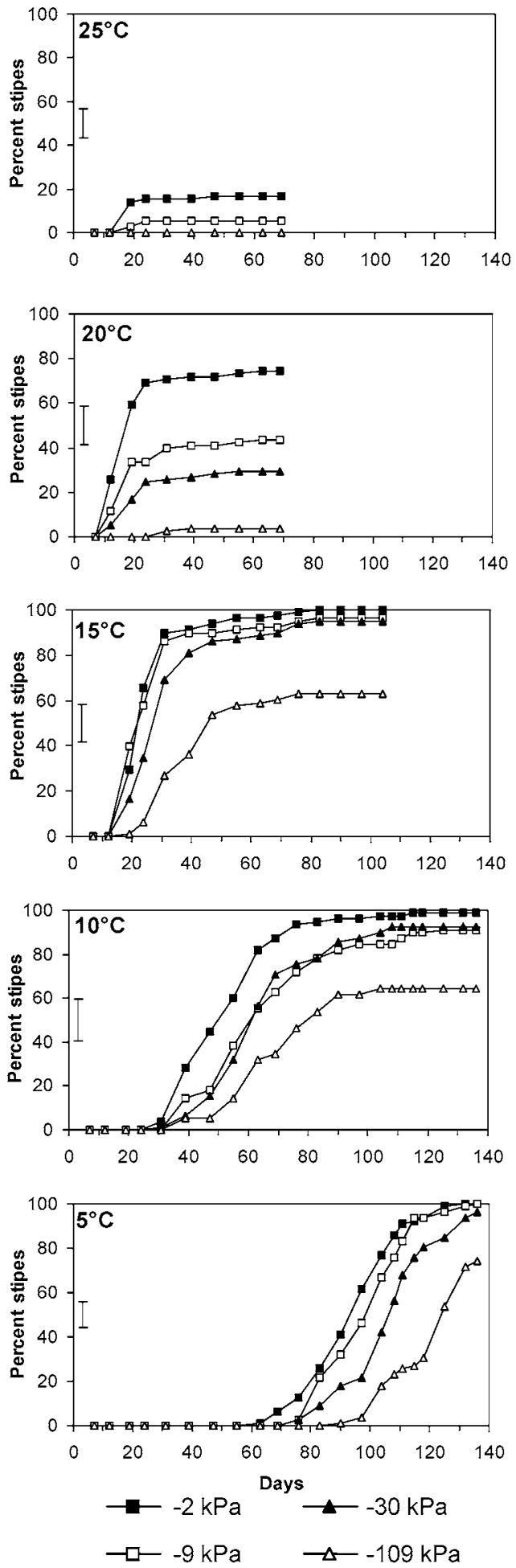

duction was delayed when sclerotia were exposed for $>8 \mathrm{~h}$ at $40^{\circ} \mathrm{C}$ and for isolate $\mathrm{TM}$ when exposed for $>12 \mathrm{~h}$. For isolate 13, stipes were first seen at 9 to 12 days for sclerotia incubated at $40^{\circ} \mathrm{C}$ for 4 or $8 \mathrm{~h}$ or maintained at a constant $15^{\circ} \mathrm{C}$ throughout (control). Longer durations at $40^{\circ} \mathrm{C}$ of 12,24 , or $48 \mathrm{~h}$ resulted in an increasing delay to stipe appearance from 14 to 35 days (Fig. 4). At the end of the experiment, after 72 days, more than $95 \%$ of

\section{S. sclerotiorum isolate TM in Norfolk silty clay}
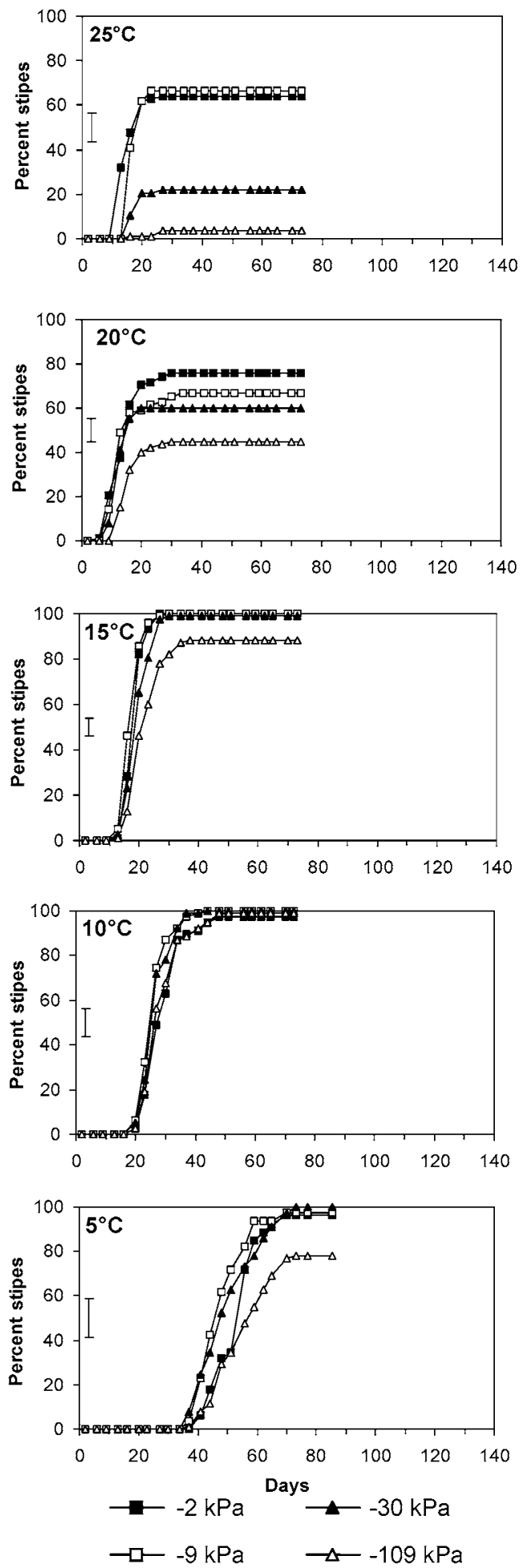

Fig. 2. Effect of water potential on percentage of Sclerotinia sclerotiorum sclerotia producing stipes for isolate 13 in a Cheshire peat $(-2,-9,-30$, and $-109 \mathrm{kPa})$ and TM in a Norfolk silty clay loam $(-2,-9,-30$, and $-107 \mathrm{kPa})$ at $10,15,18,22$, and $25^{\circ} \mathrm{C}$. Each data point is the mean of three replicates of 26 sclerotia. Bars represent standard error of the mean. There was no germination of sclerotia of S. sclerotiorum isolate 13 at $-383 \mathrm{kPa}$ in the peat soil or isolate TM at $-412 \mathrm{kPa}$ in the silty clay loam at any temperature. 
isolate 13 sclerotia exposed for up to $24 \mathrm{~h}$ at $40^{\circ} \mathrm{C}$ had germinated to produce stipes, whereas those exposed for 48 and $72 \mathrm{~h}$ resulted in only 22 and $4 \%$ germination, respectively. For S. sclerotiorum isolate TM, stipes first appeared after 21 days for a 24-h duration at $40^{\circ} \mathrm{C}$ and after 42 days for durations of 48 and $72 \mathrm{~h}$. As for isolate 13 , germination levels for isolate TM were $>95 \%$ for $40^{\circ} \mathrm{C}$ durations of 4 to $24 \mathrm{~h}$ after 72 days but were 78 and $63 \%$ for durations of 48 and $72 \mathrm{~h}$, respectively. Importantly, it was observed that durations of 48 and $72 \mathrm{~h}$ at $40^{\circ} \mathrm{C}$ resulted in myceliogenic germination of sclerotia for both $\mathrm{S}$. sclerotiorum isolates.

The durations at $35^{\circ} \mathrm{C}$ tested did not delay the appearance of stipes for $S$. sclerotiorum isolate TM and caused only a slight delay (up to $\approx 7$ days) at durations of 48 and $72 \mathrm{~h}$ for $S$. sclerotiorum isolate 13 (data not shown).

Apothecial production by sclerotia in the field. In all, 10 burials of $S$. sclerotiorum isolates 13 and TM sclerotia were carried out between April and August 2000 at the Cheshire and Norfolk field sites, respectively (B1 to B10) and, in 2001, 12 burials were made between March and August (B1 to B12). There was no degradation of sclerotia in any of the burials after 6 weeks.

Germination of buried sclerotia (isolate 13) to produce apothecia followed a similar pattern at the Cheshire field site in both years (Table 1; Fig. 5A and B). Here, for early burials made between March and mid-May (B1 to B5), apothecia appeared in 45 to 84 days and $>60 \%$ of the sclerotia germinated. For the subsequent burials, apothecia appeared in 50 to 106 days but far fewer or, in some cases, none of the sclerotia germinated $(0.5$ to $10 \%$ in 2000 and 0 to $38 \%$ in 2001). The same pattern of sclerotial germination also was observed in Norfolk (Fig. 5C and D). Here, in both years, the early burials of sclerotia between March and early May (B1 to B3 in 2000 and B1 to B5 in 2001) produced apothecia in 93 to 167 days but only reached a maximum of $67 \%$ sclerotia germinated. For the later burials, germination occurred in 73 to 125 days and only reached 0 to $9 \%$ sclerotia germinated. Hence, overall, more sclerotia germinated in Cheshire and in a shorter period of time compared with those in Norfolk. At both field sites, there also was synchronous appearance of apothecia from different burials in both years. For instance, in 2001 in Cheshire, the first three burials of sclerotia all produced new apothecia on 18 June and 13 August 2001; whereas, in Norfolk, burials 2, 3, 4, and 5 all produced new apothecia on 6 September 2001.

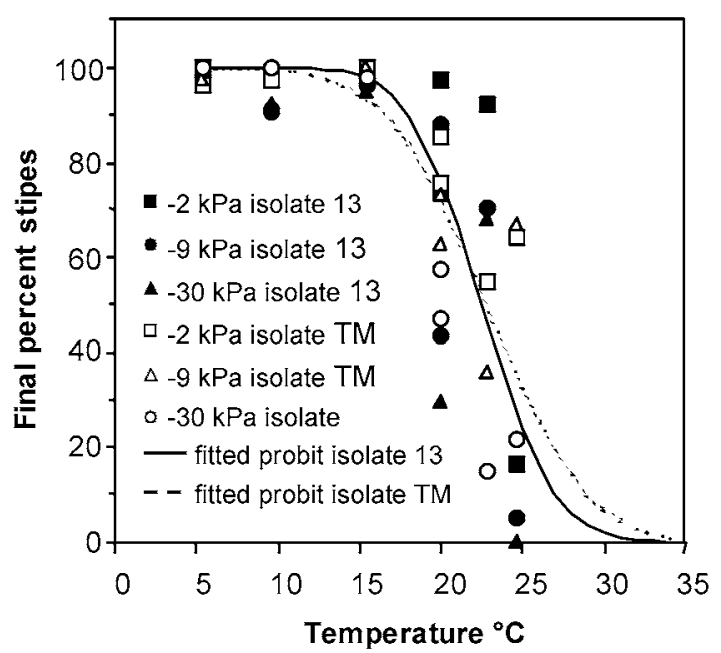

Fig. 3. Effect of temperature on final percentage of Sclerotinia sclerotiorum sclerotia producing stipes at water potentials of $-2,-9$, and $-30 \mathrm{kPa}$ for $S$. sclerotiorum isolate 13 in Cheshire peat and isolate TM in a Norfolk silty clay loam. Fitted lines are probits with equations as follows: isolate 13: $p(T)=$ $\Phi(4.66-0.205 T)$ and isolate TM: $p(T)=\Phi(6.28-0.279 T)$, where $p(T)$ is the proportion of sclerotia germinating at temperature $T$ and $\Phi$ is the normal probability integral.
At the Cheshire and Norfolk field sites, the monitoring of sclerotia in 2001 that were buried in 2000 but failed to germinate in that same year showed that some of these germinated the following year to produce apothecia (Table 2). However, overall, the total percentage of sclerotia buried in 2000 that germinated in 2000 or 2001 still was reduced for both $S$. sclerotiorum isolates in later burials made from May to August, compared with those made between March and early May.

The soil water potential data showed that the silty clay loam at the Norfolk field site was consistently drier than the peat soil at the Cheshire site in both years (Fig. 5). At the Norfolk field site, the water potential regularly dropped below $-100 \mathrm{kPa}$ from April to September 2001, and this also was a feature of the 2000 data. Temperature in the Cheshire peat soil reached a maximum of $40^{\circ} \mathrm{C}$ in 2000 and 2001 and, generally, soil temperatures from May to August were higher than in the Norfolk silty clay loam, where the maxima were $30.6^{\circ} \mathrm{C}$ in 2000 and $35.2^{\circ} \mathrm{C}$ in 2001 (data not shown).

Thermal time analysis of apothecial production by sclerotia in the field. Thermal time analysis was carried out for each burial of $S$. sclerotiorum isolate 13 sclerotia in Cheshire in 2000 and 2001 where germination reached 10 or $50 \%$, but not for isolate TM in Norfolk because few burials reached these required germination levels. Mean thermal time for the burials with no temperature or water potential threshold constraints gave no better predictions of 10 or $50 \%$ germination (T10 or T50) than using the mean chronological time to germination (Table 3). Results from the laboratory data suggested that thermal time would accrue only at temperatures above a threshold of 0 to $5^{\circ} \mathrm{C}$ and below $25^{\circ} \mathrm{C}$ and for water potentials above between -100 and $-300 \mathrm{kPa}$ (Figs. 1 and 2). Predictions of T10 and T50 with mean thermal times generated using combinations of these constraints
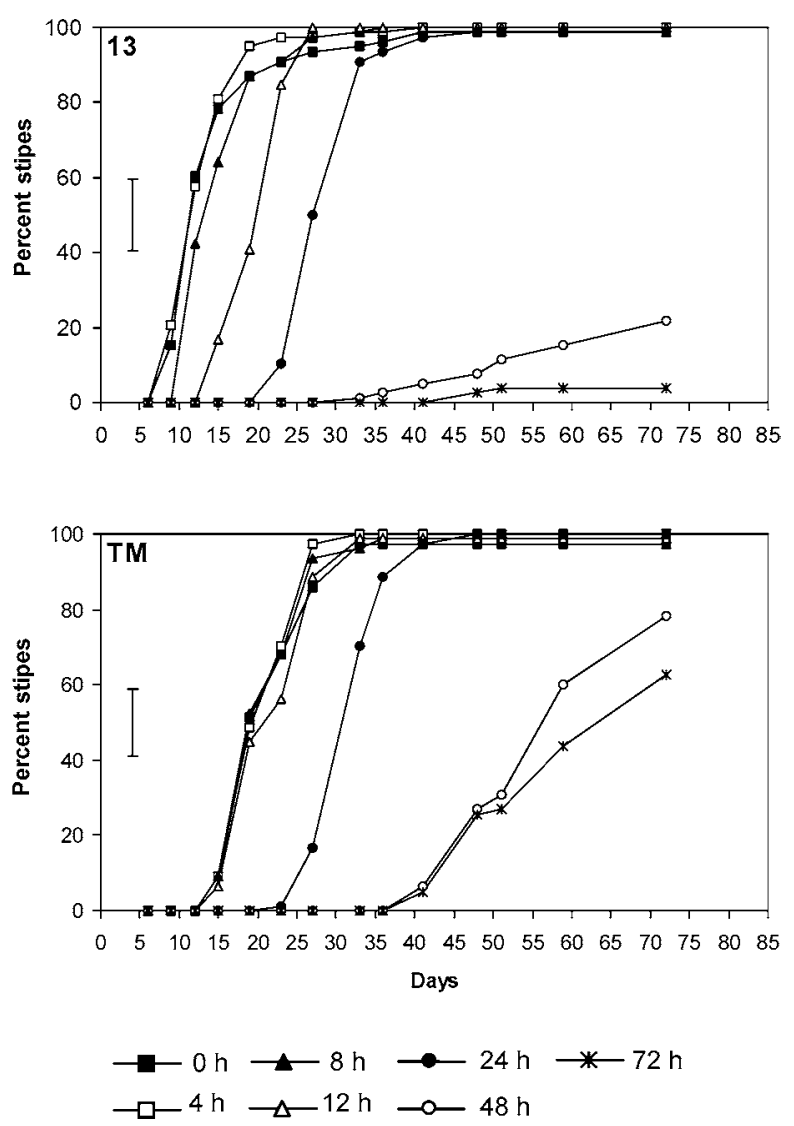

Fig. 4. Effect of durations at $40^{\circ} \mathrm{C}$ on percentage of Sclerotinia sclerotiorum sclerotia producing stipes for isolate 13 in a Cheshire peat and isolate TM in a Norfolk silty clay loam at $-2 \mathrm{kPa}$. 
also gave no improvement on the mean time to germination, although predictions were better than with no constraints (Table $3)$. However, in the field, it was noted that the time to germination increased for burials where the mean temperature was above $\approx 16^{\circ} \mathrm{C}$ (Table 1 ). When this value was used as an upper temperature threshold in combination with other constraints, predictions using the mean thermal time for the burials generally were improved considerably as shown by lower RMSE values and were, in some cases, much better than using mean time to T10 or T50 (Table 3). Use of a water potential threshold gave no improvement of predictions of germination of sclerotia, although the soil water potential at the Cheshire site rarely dropped below $-100 \mathrm{kPa}$. A base temperature of $5^{\circ} \mathrm{C}$ was the best for $\mathrm{T} 10$ predictions in 2000 and 2001 , whereas $0^{\circ} \mathrm{C}$ was better for T50 predictions in each year (Table 3 ). Based on this information and the determination of a soil water potential threshold from the laboratory experiments, thermal time was calculated for burials at Cheshire in 2000 and 2001 with temperature thresholds of $\geq 5^{\circ} \mathrm{C}$ and $\leq 16^{\circ} \mathrm{C}$ and a soil water potential threshold of $\geq-200 \mathrm{kPa}$. The mean thermal time with these constraints was 285 and 279 day-degrees for T10 and 369 and 347 day-degrees for T50 for 2000 and 2001, respectively. When these means were used to calculate the corresponding T10 and T50 date for each burial, these predictions were close to the time that germination of sclerotia to produce apothecia actually was observed (Table 1). For T10 and T50, discrepancies in predicted times to germination ranged from -15 to +9 days in 2000 and -14 to +18 days in 2001 compared with the observed germination time. The mean thermal time to germination in the field at Cheshire in both years also was converted to rates corresponding to the temperatures used in the laboratory studies. It was found that these germination rates were similar to those for the experiments assessing production of apothecia under controlled conditions (data not shown).

\section{DISCUSSION}

Soil temperature and water potential clearly were major factors affecting the carpogenic germination of $S$. sclerotiorum sclerotia in this study, which confirms previous reports $(18,30)$. In experiments investigating both apothecial production in the light and stipe production in the dark at constant temperatures, there was a clear soil water potential threshold of $\approx-100 \mathrm{kPa}$ for $S$. sclerotiorum isolate 13 in the Cheshire peat soil and isolate TM in the Norfolk silty clay loam. Lower water potentials ( -380 and $-410 \mathrm{kPa}$, respectively) were unable to support germination of sclerotia and these results confirm those of Hao et al. (18). Hence, the two $S$. sclerotiorum isolates were almost identical in their response to soil water potential. Although some researchers have demonstrated germination of sclerotia at -400 and $-750 \mathrm{kPa}(26,37)$, our results also suggest, as do others $(14,16)$, that soil with a high water content (but not completely saturated) is necessary for apothecial production by $S$. sclerotiorum sclerotia.

Sclerotia of both $S$. sclerotiorum isolates germinated carpogenically between 5 and $25^{\circ} \mathrm{C}$, but there was negligible germination of sclerotia at 26 and $29^{\circ} \mathrm{C}$. The final percent germination decreased considerably with temperatures approaching $25^{\circ} \mathrm{C}$ compared with temperatures of $\leq 20^{\circ} \mathrm{C}$. Other researchers also have shown that few apothecia of $S$. sclerotiorum are produced at 25 or $30^{\circ} \mathrm{C}(1,18,36)$. A small temperature shift from 25 to $26^{\circ} \mathrm{C}$ almost completely inhibited carpogenic germination and there was some degree of variation in the final percent sclerotia germinated around these temperatures. This phenomenon may be due to the inherent variability of the fungus (10), resulting in differences between batches of sclerotia grown in the laboratory and the large effect on final germination of a small temperature shift.

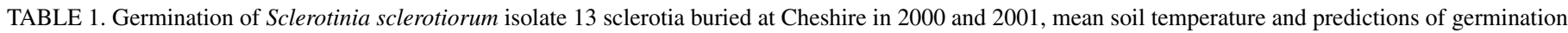
using thermal time

\begin{tabular}{|c|c|c|c|c|c|c|c|c|}
\hline Burial no. & Burial date & $\begin{array}{c}\text { Germinated } \\
(\%)^{\mathrm{a}}\end{array}$ & $\begin{array}{c}\text { Obs } \\
(\text { days })^{b}\end{array}$ & $\begin{array}{l}\text { Mean temp } \\
\left({ }^{\circ} \mathrm{C}\right)^{\mathrm{c}}\end{array}$ & $\begin{array}{l}\text { T10 obs } \\
\text { (days) }^{\mathrm{d}}\end{array}$ & $\begin{array}{l}\text { T10 pred } \\
\text { (days) }^{\mathrm{e}}\end{array}$ & 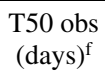 & $\begin{array}{l}\text { T50 pred } \\
\text { (days) }^{\mathrm{g}}\end{array}$ \\
\hline \multicolumn{9}{|c|}{ Cheshire 2000} \\
\hline 1 & 03 April & 95.0 & 66.0 & 13.6 & 78.5 & 78.8 & 86.1 & 100.3 \\
\hline 2 & 17 April & 86.0 & 45.0 & 15.1 & 76.0 & 75.0 & 115.2 & 101.2 \\
\hline 3 & 01 May & 86.5 & 73.0 & 16.3 & 88.4 & 76.0 & 120.4 & 111.4 \\
\hline 4 & 15 May & 76.0 & 78.0 & 17.2 & 78.5 & 80.3 & 108.2 & 109.8 \\
\hline 5 & 29 May & 60.0 & 64.0 & 18.0 & 80.8 & 90.0 & 106.3 & 109.1 \\
\hline 6 & 12 June & 1.5 & 78.0 & 18.1 & $\ldots$ & 89.1 & $\ldots$ & 105.9 \\
\hline 7 & 27 June & 1.5 & 98.0 & 17.8 & $\ldots$ & 84.7 & $\ldots$ & 99.3 \\
\hline 8 & 10 July & 9.9 & 77.0 & 17.3 & $\ldots$ & 80.3 & $\ldots$ & 98.1 \\
\hline 9 & 25 July & 2.5 & 62.0 & 16.4 & $\ldots$ & 73.9 & $\ldots$ & 92.9 \\
\hline 10 & 07 August & 0.5 & 70.0 & 15.0 & $\ldots$ & 68.5 & $\ldots$ & $\ldots$ \\
\hline \multicolumn{9}{|c|}{ Cheshire 2001} \\
\hline 1 & $08 \mathrm{March}$ & 94.8 & 84.0 & 10.8 & 95.0 & 93.9 & 105.3 & 123.1 \\
\hline 2 & $22 \mathrm{March}$ & 95.3 & 70.0 & 12.0 & 83.3 & 85.3 & 107.6 & 115.8 \\
\hline 3 & 05 April & 95.0 & 63.0 & 13.4 & 73.6 & 80.1 & 116.1 & 110.0 \\
\hline 4 & 19 April & 97.0 & 60.0 & 16.3 & 103.1 & 90.1 & 120.8 & 113.3 \\
\hline 5 & 03 May & 90.5 & 49.0 & 18.2 & 98.4 & 92.9 & 122.0 & 115.3 \\
\hline 6 & 17 May & 1.0 & 106.0 & 18.9 & $\ldots$ & 96.1 & $\ldots$ & 114.7 \\
\hline 7 & 31 May & 0.0 & $\ldots$ & $\ldots$ & $\ldots$ & 96.1 & $\ldots$ & 110.4 \\
\hline 8 & 14 June & 38.3 & 96.0 & 18.7 & 91.3 & 93.7 & $\ldots$ & 105.7 \\
\hline 9 & 28 June & 27.3 & 82.0 & 18.2 & 83.6 & 87.4 & $\ldots$ & 99.0 \\
\hline 10 & 12 July & 8.5 & 68.0 & 17.3 & $\ldots$ & 76.4 & $\ldots$ & 87.7 \\
\hline 11 & 26 July & 2.8 & 64.0 & 16.9 & $\ldots$ & 71.3 & $\ldots$ & 82.7 \\
\hline 12 & 09 August & 0.3 & 50.0 & 15.5 & $\ldots$ & 62.5 & $\ldots$ & 73.4 \\
\hline
\end{tabular}

${ }^{a}$ Final percent germination of sclerotia producing apothecia of total buried sclerotia; mean of four replicates of 50 (2000) or 100 (2001).

b Time (days) to first observation of apothecia from buried sclerotia.

c Mean soil temperature from time of burial to predicted time to $10 \%$ germination of sclerotia (T10 pred).

d Observed time (days) to $10 \%$ germination of sclerotia to produce apothecia.

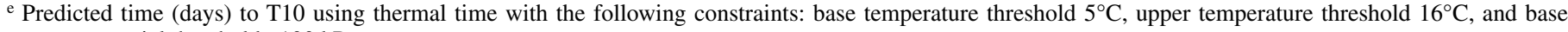
water potential threshold $-100 \mathrm{kPa}$.

${ }^{\mathrm{f}}$ Observed time (days) to $50 \%$ germination of sclerotia to produce apothecia.

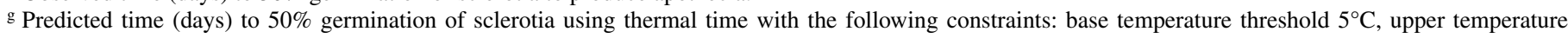
threshold $16^{\circ} \mathrm{C}$, and base water potential threshold $-100 \mathrm{kPa}$. 
A Cheshire 2000

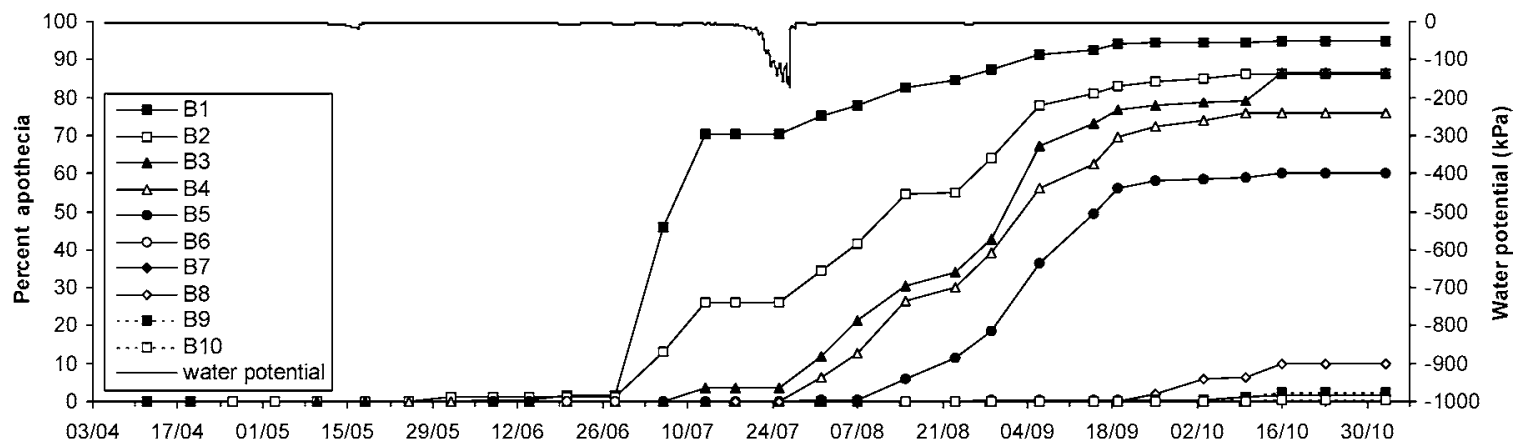

B Cheshire 2001

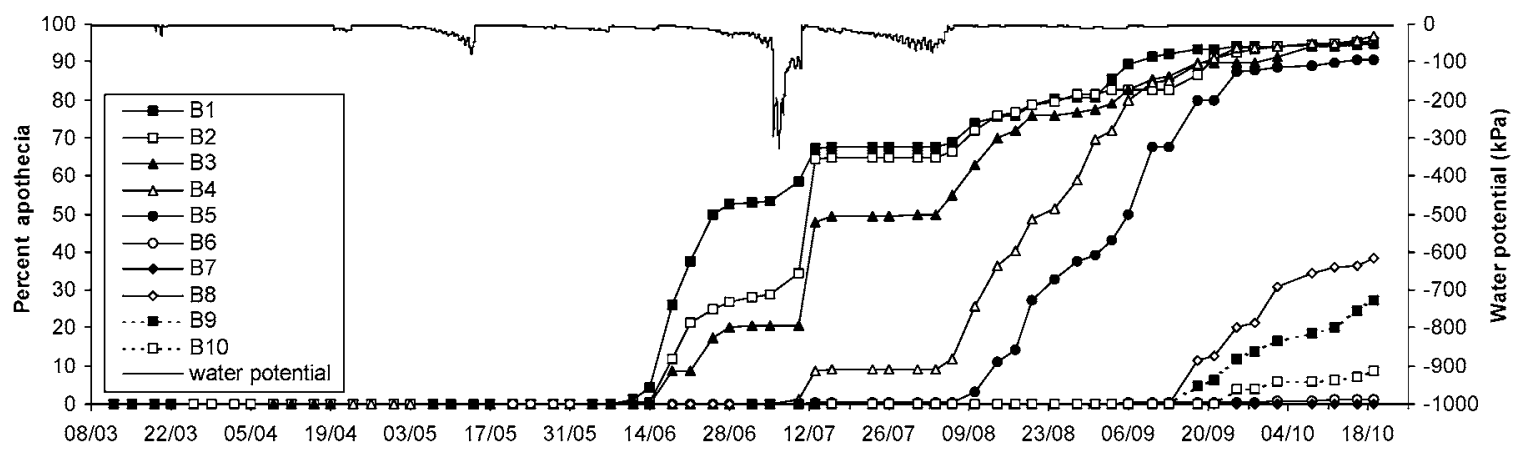

C Norfolk 2000

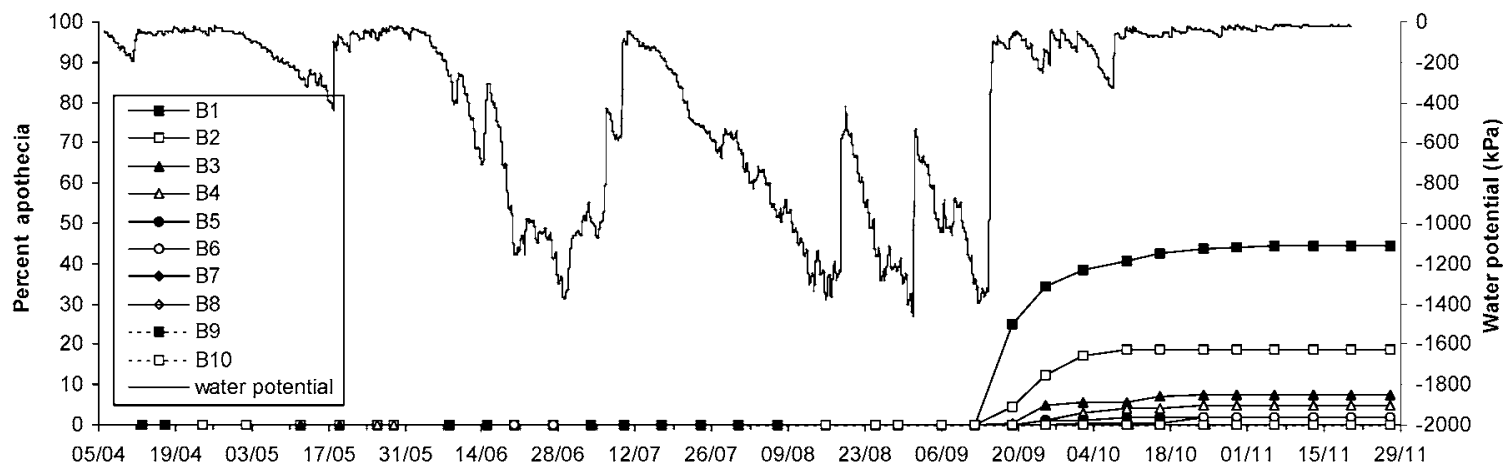

D Norfolk 2001

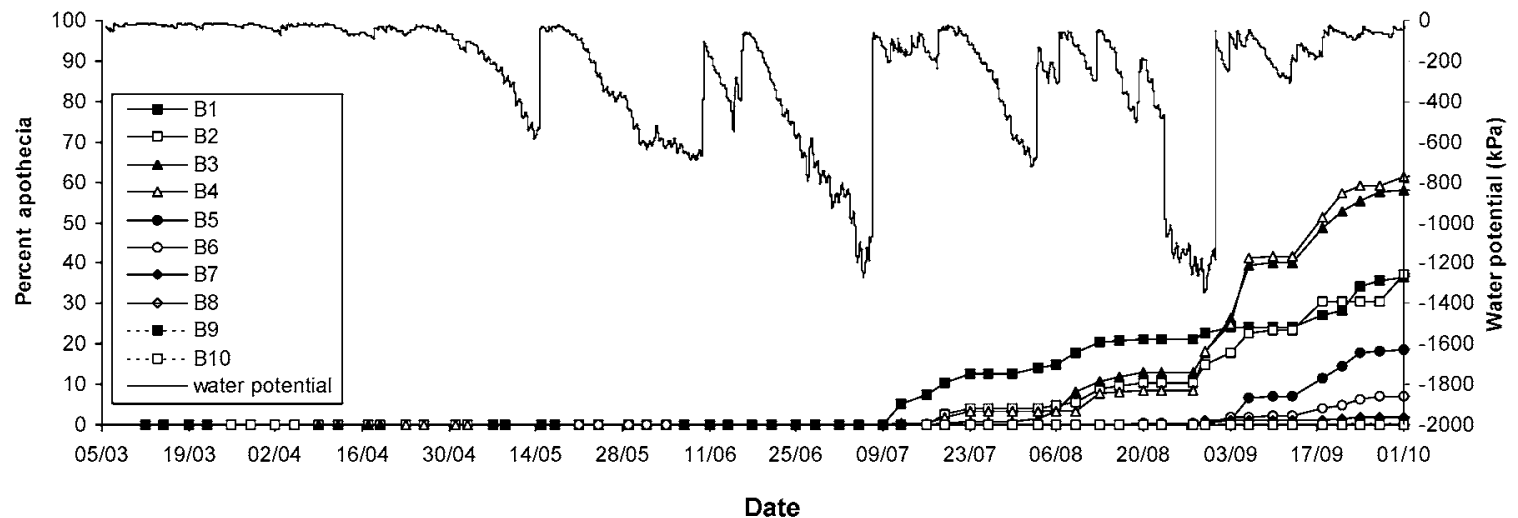

Fig. 5. Soil water potential and percentage buried Sclerotinia sclerotiorum sclerotia producing apothecia for A, isolate 13 in Cheshire in 2000 , B, isolate 13 in Cheshire in 2001, C, isolate TM in Norfolk in 2000, and D, isolate TM in Norfolk in 2001. Data points for germination of sclerotia are means of four replicates of 50 sclerotia (2000) or 100 sclerotia (2001). 
Temperature also affected the rate of carpogenic germination. The appearance of stipes or apothecia from germinating sclerotia slowed considerably at temperatures of $\leq 10^{\circ} \mathrm{C}$ compared with $\geq 15^{\circ} \mathrm{C}$. Isolate $\mathrm{TM}$ from Norfolk also germinated slightly more rapidly than isolate 13 from Cheshire at lower temperatures. For both $S$. sclerotiorum isolates, stipes were first produced at 39 to 41 days and apothecia at 48 to 54 days at $10^{\circ} \mathrm{C}$, compared with 27 to 34 days for stipes and apothecia at 15 to $20^{\circ} \mathrm{C}$. By comparison, Singh and Singh (33) first observed stipes from sclerotia after $\approx 30$ days in a silty clay loam at $15^{\circ} \mathrm{C}$, with apothecia forming after 41 to 44 days. However, in the same experiment, stipes were first observed in sand after 14 to 16 days, with apothecia forming after 23 to 25 days. Mylchreest and Wheeler (27) observed stipes

TABLE 2. Germination of Sclerotinia sclerotiorum sclerotia in 2000 and 2001 that were buried in 2000 at Cheshire (isolate 13) and Norfolk (isolate TM)

\begin{tabular}{llccc}
\hline Burial no. & Burial date & $\begin{array}{c}\text { Germination } \\
2000(\%)^{\mathrm{a}}\end{array}$ & $\begin{array}{c}\text { Germination } \\
2001(\%)^{\mathrm{a}}\end{array}$ & $\begin{array}{c}\text { Total } \\
(\%)\end{array}$ \\
\hline Cheshire & & & & \\
1 & 03 April 2000 & 95.0 & 0.0 & 95.0 \\
2 & 17 April 2000 & 86.0 & 3.0 & 89.0 \\
3 & 01 May 2000 & 86.5 & 3.0 & 89.5 \\
4 & 15 May 2000 & 76.0 & 7.0 & 83.0 \\
5 & 29 May 2000 & 60.0 & 10.5 & 70.5 \\
6 & 12 June 2000 & 1.5 & 37.0 & 38.5 \\
7 & 27 June 2000 & 1.5 & 39.0 & 40.5 \\
8 & 10 July 2000 & 10.0 & 39.0 & 49.0 \\
9 & 25 July 2000 & 2.5 & 41.5 & 44.0 \\
10 & 07 August 2000 & 0.5 & 33.5 & 34.0 \\
Norfolk & & & & \\
1 & 05 April 2000 & 44.5 & 6.5 & 51.0 \\
2 & 17 April 2000 & 18.5 & 12.0 & 30.5 \\
3 & 08 May 2000 & 7.5 & 22.5 & 30.0 \\
4 & 17 May 2000 & 5.0 & 14.5 & 19.5 \\
5 & 30 May 2000 & 2.0 & 13.5 & 15.5 \\
6 & 12 June 2000 & 2.0 & 23.0 & 25.0 \\
7 & 27 June 2000 & 0.0 & 34.5 & 34.5 \\
8 & 10 July 2000 & 0.0 & 4.5 & 4.5 \\
9 & 24 July 2000 & 0.0 & 19.5 & 19.5 \\
10 & 07 August 2000 & 0.0 & 13.5 & 13.5 \\
\hline & & & & \\
\hline
\end{tabular}

a Final percent germination of sclerotia producing apothecia of total buried (mean of four replicates of 50 sclerotia). from sclerotia in potting compost at $10^{\circ} \mathrm{C}$ after $\approx 42$ days and Phillips (29) first saw germination of surface-sterilized sclerotia on moist perlite after 6 days at $18^{\circ} \mathrm{C}$. Teo and Morall (37) observed apothecia after 21 days in a sandy loam at $15^{\circ} \mathrm{C}$ with water potential in the range of -10 to $-100 \mathrm{kPa}$, while Hao et al. (18) first saw stipes after 28 days at optimum temperature. Other studies, therefore, show a similar rate of sclerotial germination to that observed at the appropriate temperatures presented here. Variation between results could be due to factors such as variability between isolates of different geographic origin (22), conditioning period of sclerotia (29), or different soil water potentials. Carpogenic germination of $S$. sclerotiorum sclerotia also occurred at $5^{\circ} \mathrm{C}$ in this study, where almost $100 \%$ sclerotia eventually germinated and stipes were first seen after 37 to 63 days. This confirms the results of Smith and Boland (35), where stipes were formed on sclerotia in damp sand at $4^{\circ} \mathrm{C}$ after 28 to 280 days, depending on the isolate. This need for a long incubation time for germination to occur in some isolates may explain why other researchers have reported little or no germination at $5^{\circ} \mathrm{C}(1,18)$.

Analysis of the laboratory data showed that temperature had significant effects on both germination rate and final number of sclerotia germinated, but soil water potential had little effect on either variate provided it was above the $-100-\mathrm{kPa}$ threshold. There was no interaction of temperature and water potential. This confirms the results of Teo and Morall (37), who reported that there was no clear interaction between the rate of sclerotial germination and water potential at $15^{\circ} \mathrm{C}$. The relationships derived from the laboratory data form a strong basis for a forecasting system for carpogenic germination. Temperature and sclerotial germination rate were correlated strongly and, generally, there was little difference in these rates between the two $S$. sclerotiorum isolates, suggesting that they are similarly adapted to U.K. conditions. Rates of germination derived from experiments where stipe production was monitored for sclerotia on the soil surface were, of course, faster than those derived from buried sclerotia producing apothecia under controlled conditions. The difference represents the time taken for a stipe to reach the soil surface and further develop into an apothecium. This illustrates that the burial depth of sclerotia in the field and factors affecting development of

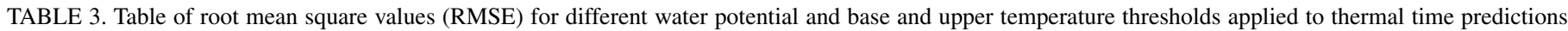
of germination of Sclerotinia sclerotiorum sclerotia at Cheshire in 2000 and 2001 ${ }^{\mathrm{a}}$

\begin{tabular}{|c|c|c|c|c|c|c|}
\hline \multirow[b]{2}{*}{ Water potential threshold $(\mathrm{kPa})$} & \multicolumn{2}{|c|}{ Temperature threshold } & \multicolumn{2}{|c|}{ Cheshire 2000} & \multicolumn{2}{|c|}{ Cheshire 2001} \\
\hline & Base $\left({ }^{\circ} \mathrm{C}\right)$ & Upper $\left({ }^{\circ} \mathrm{C}\right)$ & $\mathrm{T} 10^{\mathrm{b}}$ & $\mathrm{T} 50^{\mathrm{c}}$ & $\mathrm{T} 10^{\mathrm{b}}$ & $\mathrm{T} 50^{\mathrm{c}}$ \\
\hline-100 & 0 & 16 & 115.3 & 143.9 & 123.8 & 31.8 \\
\hline-100 & 0 & 25 & 69.7 & 349.2 & 270.3 & 320.9 \\
\hline-100 & 0 & None & 121.3 & 373.6 & 394.8 & 472.6 \\
\hline-100 & 5 & 16 & 58.0 & 168.2 & 44.5 & 131.8 \\
\hline-100 & 5 & 25 & 110.2 & 430.4 & 466.4 & 519.7 \\
\hline-100 & 5 & None & 174.0 & 447.7 & 576.1 & 672.3 \\
\hline-200 & 0 & 16 & 115.3 & 143.9 & 123.8 & 31.8 \\
\hline-200 & 0 & 25 & 69.7 & 349.2 & 255.2 & 319.7 \\
\hline-200 & 0 & None & 121.3 & 373.6 & 362.3 & 476.1 \\
\hline-200 & 5 & 16 & 58.0 & 168.2 & 44.5 & 131.8 \\
\hline-200 & 5 & 25 & 110.2 & 430.4 & 452.3 & 518.4 \\
\hline-200 & 5 & None & 174.0 & 447.7 & 543.7 & 677.9 \\
\hline None & 0 & 16 & 150.8 & 165.4 & 123.9 & 31.9 \\
\hline None & 0 & 25 & 72.2 & 349.2 & 223.8 & 327.4 \\
\hline None & 0 & None & 100.5 & 373.8 & 325.8 & 480.9 \\
\hline None & 5 & 16 & 80.2 & 148.2 & 44.4 & 131.7 \\
\hline None & 5 & 25 & 106.3 & 430.1 & 398.2 & 517.1 \\
\hline None & 5 & None & 146.5 & 447.9 & 492.5 & 682.3 \\
\hline $\mathrm{RMSE}^{\mathrm{d}}$ & $\ldots$ & $\ldots$ & 35.4 & 205.4 & 103.9 & 58.1 \\
\hline
\end{tabular}


apothecia also will be important when deriving appropriate germination rates to incorporate into a forecasting system. However, rates of germination derived from the thermal time analysis of sclerotia buried in the field corresponded well with those derived from buried sclerotia in the laboratory experiments under controlled conditions, suggesting that the laboratory approach was realistic and that sclerotia responded to temperature similarly for both constant and fluctuating conditions. Further data are required in order to determine an accurate relationship between germination rate and temperature, which would be an essential component of a forecasting system for carpogenic germination. As well as the germination rate component, a forecasting system for carpogenic germination also should incorporate the relationship between temperature and the final percent sclerotia germinated as described by the probit model derived in this study. The threshold soil water potential below which no germination occurs also should be included. Equivalent components to these have been combined successfully by Alvarado and Bradford (3) and Grundy et al. (17) in models predicting seed germination based on that of Washatani (39), and also have been used to explain the germination of sclerotia of Botrytis squamosa (11). However, combining components of sclerotial germination derived from the laboratory studies to produce a forecasting system of carpogenic germination would be premature at this stage and, although the thermal time analysis of the field data in this study did have some value as a predictor of appearance of apothecia in the field, neither approach currently could be used with confidence. This is because the lack of germination of some of the burials of sclerotia in the field could not be explained either by the thermal time analysis or by the results obtained in the laboratory under controlled conditions, and the two approaches sometimes were contradictory. First, although water potentials of $<-100 \mathrm{kPa}$ prevented carpogenic germination of $S$. sclerotiorum sclerotia in laboratory experiments, the thermal time analysis showed that thresholds of -100 or $-200 \mathrm{kPa}$ did not improve predictions of carpogenic germination in the field at Cheshire. This probably is because the soil water potential at this field site rarely fell below these thresholds. This was in contrast to the Norfolk field soil, where such dry conditions were more frequent, and is the likely explanation for the longer time required for many of the Norfolk burials of sclerotia to germinate. Therefore, a water potential threshold would be more important in a potential forecasting system for a dry field site such as Norfolk, but could not be tested in this study because the final germination levels of the buried sclerotia generally were not high enough for analysis.

Second, thermal time analysis for the sclerotia buried at Cheshire also showed that the best prediction of germination was when an upper temperature threshold of $16^{\circ} \mathrm{C}$ was used, whereas the probit model derived from the laboratory data suggested a threshold of $25^{\circ} \mathrm{C}$. This discrepancy requires further investigation. Finally, neither thermal time analysis nor the probit model relating temperature and final percent germination of sclerotia could account for the poor germination of most of the later burials of sclerotia at Cheshire (burial 6 onward) in 2000 and 2001. It was clear from the field environmental data that the probit model could not describe the large decreases in germination levels observed between burials 5 (60 to $90 \%$ germination) and $6(1 \%$ germination) at Cheshire in both 2000 and 2001. Because these burials were consecutive, they largely shared the same weather conditions, except for the 2 weeks between them. Preliminary examination of this data showed that both burials were subjected to a period where temperatures reached $35^{\circ} \mathrm{C}$, but that this period occurred earlier in the thermal time accumulated for burial 6 than burial 5. Hence, unexpected effects on sclerotia exposed to high temperature at a critical time may have been responsible for the large difference in final germination between these two burials and the failure of later burials to germinate significantly. However, exposure of sclerotia to durations of up to $48 \mathrm{~h}$ at $35^{\circ} \mathrm{C}$ did not affect sclerotia in the laboratory and only durations of $>24 \mathrm{~h}$ at $40^{\circ} \mathrm{C}$ delayed and reduced the number of sclerotia germinating irreversibly by initiating myceliogenic germination. This type of germination also has been reported for $S$. sclerotiorum sclerotia exposed to other environmental stresses such as desiccation, freezing, and repeated wetting and drying cycles $(19,20,34)$. Nevertheless, even though temperatures in the field at Cheshire and Norfolk in 2000 and 2001 reached $40^{\circ} \mathrm{C}$ for only a few hours or reached a maximum of just 30 or $35^{\circ} \mathrm{C}$, this still may have had the effect of suppressing carpogenic germination of sclerotia with regular exposure over time. This hypothesis deserves further investigation.

The results from this study suggest that the development of a forecasting system for carpogenic germination of S. sclerotiorum in the field to produce apothecia is feasible. Relationships among temperature, germination rate, and final percent sclerotia germinated, as well as a clear minimum soil water potential threshold required for carpogenic germination derived in this study, provide a basis for prediction. The thermal time approach also has some value as a predictor of germination. However, the field results showed that there still are some other outstanding effects of environmental factors to be understood before an accurate prediction of carpogenic germination can be achieved. The effect of exposure of sclerotia to high temperatures for short durations in a fluctuating environment, as well as the effect of the timing of such occasions in relation to the progress of sclerotia toward germination, may be critical. In addition, because S. sclerotiorum sclerotia in the field are subjected to fluctuating soil moisture conditions as well, this also may influence germination in a way not predicted by using a simple threshold water potential and is another factor which must be investigated. Experiments reported here used sclerotia produced in the laboratory and used two $S$. sclerotiorum isolates. Ideally, the response of sclerotia to temperature and soil water potential should be compared with more isolates and also with sclerotia formed naturally in the field to determine if a single forecasting system for carpogenic germination is appropriate for all regions in the United Kingdom.

\section{ACKNOWLEDGMENTS}

We thank the Department for Environment, Food, and Rural Affairs for financial support through projects HH1729TFV and HV3215TFV; and J. Yurkwich for technical support.

\section{LITERATURE CITED}

1. Abawi, G. S., and Grogan, R. G. 1975. Source of primary inoculum and effects of temperature and moisture on infection of beans by Whetzelina sclerotiorum. Phytopathology 65:300-309.

2. Abawi, G. S., and Grogan, R. G. 1979. Epidemiology of diseases caused by Sclerotinia species. Phytopathology 69:899-903.

3. Alvarado, V., and Bradford, K. J. 2002. A hydrothermal time model explains the cardinal temperatures for seed germination. Plant Cell Environ. 25:1061-1069.

4. Bardin, S. D., and Huang, H. C. 2001. Research on biology and control of Sclerotinia diseases in Canada. Can. J. Plant Pathol. 23:88-98.

5. Ben-Yephet, Y., Genizi, A., and Siti, E. 1993. Sclerotial survival and apothecial production by Sclerotinia sclerotiorum following outbreaks of lettuce drop. Phytopathology 83:509-513.

6. Boland, G. J., and Hall, R. 1988. Epidemiology of Sclerotinia stem rot of soybean in Ontario. Phytopathology 78:1241-1245.

7. Boland, G. J., and Hall, R. 1988. Relationships between the spatial pattern and number of apothecia of Sclerotinia sclerotiorum and stem rot of soybean. Plant Pathol. 37:329-336.

8. Boland, G. J., and Hall, R. 1994. Index of plant hosts of Sclerotinia sclerotiorum. Can. J. Plant Pathol. 16:93-108.

9. Bourdot, G. W., Hurrell, G. A., Saville, D. J., and De Jong, M. D. 2001. Risk analysis of Sclerotinia sclerotiorum for biological control of Cirsium arvense in pasture: Ascospore dispersal. Biocontrol Sci. Technol. 11:119-139.

10. Carpenter, M. A., Frampton, C., and Stewart, A. 1999. Genetic variation in New Zealand populations of the plant pathogen Sclerotinia sclerotiorum. N.Z. J. Crop Hortic. Sci. 27:13-21. 
11. Clarkson, J. P., Kennedy, R., and Phelps, K. 1999. The effect of temperature and water potential on the production of conidia by sclerotia of Botrytis squamosa. Plant Pathol. 49:119-128.

12. DEFRA Horticultural Statistics. 2002. Vegetable Crops. Published online by the Department for Environment Food and Rural Affairs.

13. Dillard, H. R., Ludwig, J. W., and Hunter, J. E. 1995. Conditioning sclerotia of Sclerotinia sclerotiorum for carpogenic germination. Plant Dis. 79:411-415.

14. Ferraz, L. C. L., Cafe, A. C., Nasser, L. C. B., and Azevedo, J. 1999. Effects of soil moisture, organic matter and grass mulching on the carpogenic germination of sclerotia and infection of bean by Sclerotinia sclerotiorum. Plant Pathol. 48:77-82.

15. Finney, D. J. 1971. Probit Analysis. Cambridge University Press, UK.

16. Grogan, R. G., and Abawi, G. S. 1975. Influence of water potential on growth and survival of Whetzelina sclerotiorum. Phytopathology 65:122138.

17. Grundy, A. C., Phelps, K., Reader, R. J., and Burston, S. 2000. Modelling the germination of Stellaria media using the concept of hydrothermal time. New Phytol. 148:433-444.

18. Hao, J. J., Subbarao, K. V., and Duniway, J. M. 2003. Germination of Sclerotinia minor and S. sclerotiorum sclerotia under various soil moisture and temperature combinations. Phytopathology 93:443-450.

19. Huang, H. C. 1991. Induction of myceliogenic germination of sclerotia of Sclerotinia sclerotiorum by exposure to sub-freezing temperatures. Plant Pathol. 40:621-625.

20. Huang, H. C., Chang, C., and Kozub, G. C. 1998. Effect of temperature during sclerotial formation, sclerotial dryness, and relative humidity on myceliogenic germination of sclerotia of Sclerotinia sclerotiorum. Can. J. Bot. 76:494-499.

21. Huang, H. C., and Kozub, G. C. 1989. A simple method for production of apothecia from sclerotia of Sclerotinia sclerotiorum. Plant Prot. Bull. ROC 31:333-345.

22. Huang, H. C., and Kozub, G. C. 1991. Temperature requirements for carpogenic germination of sclerotia of Sclerotinia sclerotiorum isolates of different geographic origin. Bot. Bull. Acad. Sin. 32:279-286.

23. Huang, H. C., and Kozub, G. C. 1993. Influence of inoculum production temperature on carpogenic germination of sclerotia of Sclerotinia sclerotiorum. Can. J. Microbiol. 39:548-550.

24. Hunter, J. E., Pearson, R. C., Seem, R. C., Smith, C. A., and Palumbo, D. R. 1984. Relationship between soil moisture and occurrence of Sclerotinia sclerotiorum and white mold disease on snap beans. Prot. Ecol. 7:269-280.

25. Kruger, W. 1975. Die beeinflussung der apothezien und ascosporen entwicklung des rapskrebserregers Sclerotinia sclerotiorum (Lib.) de Bary. Durch umweltfaktoren. J. Plant Dis. Prot. 82:101-108.
26. Morrall, R. A. A. 1977. A preliminary study of the influence of water potential on sclerotium germination in Sclerotinia sclerotiorum. Can. J. Bot. 55:8-11.

27. Mylchreest, S. J., and Wheeler, B. E. J. 1987. A method for inducing apothecia from sclerotia of Sclerotinia sclerotiorum. Plant Pathol. 36:16-20.

28. Patterson, C. L., and Grogan, R. G. 1985. Differences in epidemiology and control of lettuce drop caused by Sclerotinia minor and Sclerotinia sclerotiorum. Plant Dis. 69:766-770.

29. Phillips, A. J. L. 1986. Carpogenic germination of sclerotia of Sclerotinia sclerotiorum after periods of conditioning in soil. J. Phytopathol. 116:247-258.

30. Phillips, A. J. L. 1987. Carpogenic germination of sclerotia of Sclerotinia sclerotiorum: A review. Phytophylactica 19:279-283.

31. Sansford, C. E. 1995. Oilseed rape: An aid to Sclerotinia forecasting. Pages 1007-1009 in: Proc. IX Int. Rapeseed Congr. D. Murphy, ed. Cambridge, UK

32. Sansford, C. E., and Coley-Smith, J. R. 1992. Production and germination of sclerotia of Sclerotinia sclerotiorum. Plant Pathol. 41:154-156.

33. Singh, U. P., and Singh, R. B. 1983. The effect of soil texture, soil mixture, soil-moisture and depth of soil on carpogenic germination of Sclerotinia sclerotiorum. J. Plant Dis. Prot. 90:662-669.

34. Smith, A. M. 1972. Biological control of fungal sclerotia in soil. Soil Biol. Biochem. 4:131-134.

35. Smith, E. A., and Boland, G. J. 1989. A reliable method for the production and maintenance of germinated sclerotia of Sclerotinia sclerotiorum. Can. J. Plant Pathol. 11:45-48.

36. Sun, P., and Yang, X. B. 2000. Light, temperature, and moisture effects on apothecium production of Sclerotinia sclerotiorum. Plant Dis. 84:12871293.

37. Teo, B. K., and Morrall, R. A. A. 1985. Influence of matric potentials on carpogenic germination of sclerotia of Sclerotinia sclerotiorum. 1. Development of an inclined box technique to observe apothecium production. Can. J. Plant Pathol. 7:359-364.

38. Twengstrom, E., Sigvald, R., Svensson, C., and Yuen, J. 1998. Forecasting Sclerotinia stem rot in spring sown oilseed rape. Crop Prot. 17:405-411.

39. Washatani, I. 1987. A convenient screening test system and a model for thermal germination responses of wild plant seeds: Behaviour of model and real seeds in the system. Plant Cell Environ. 10:587-598.

40. Wegulo, S. N., Sun, P., Martinson, C. A., and Yang, X. B. 2000. Spread of Sclerotinia stem rot of soybean from area and point sources of apothecial inoculum. Can. J. Plant Sci. 80:389-402.

41. Wurr, D. C. E., Fellows, J. R., and Phelps, K. 2002. Crop scheduling and prediction-principles and opportunities with field vegetables. Adv. Agron. 76:202-234 